\title{
On three new high-altitude endemic leiodids (Coleoptera: Leiodidae) from the Balkan Peninsula
}

\author{
Srećko B. Ćurčić, Božidar P. M. Ćurčić, Slobodan E. Makarov, Bojan M. Mitić \\ \& Branislava Mihajlova
}

Ćurčić, S. B., Ćurčić, B. P. M., Makarov, S. E., Mitić, B. M. \& Mihajlova, B. 2005: On three new high-altitude endemic leiodids (Coleoptera: Leiodidae) from the Balkan Peninsula. - Entomol. Fennica 16: 309-316.

Three new leiodid beetle species, viz. Petkovskiella henrikenghoffi sp. n. (Republic of Macedonia, Mt. Dautica), Babuniella jovanhadzii sp. n. (Republic of Macedonia, Mt. Karadžica) and Magdelainella milojebrajkovici sp. n. (Serbia, Mt. Javor), are described and diagnostified. Both adult genitalia and other taxonomically important characters are illustrated. Babuniella Z. Karaman is given a full generic status. All new species studied are clearly distinct from their closest congeners. These forms are of the Tertiary or even pre-Tertiary origin and age, and represent both relicts and endemics inhabiting central and southern areas of the Balkan Peninsula.

S. B. Ćurčić, B. P. M. Ćurčić, S. E. Makarov \& B. M. Mitić, Institute of Zoology, Faculty of Biology, University of Belgrade, Studentski Trg 16, 11000 Belgrade, Serbia and Montenegro; E-mail: srecko@bf.bio.bg.ac.yu, bcurcic@bf.bio. bg.ac.yu,slobodan@bf.bio.bg.ac.yu,bojan@bf.bio.bg.ac.yu

B. Mihajlova, National Museum of Natural History, Bulevar Ilinden 86, 1000 Skopje, Republic of Macedonia; E-mail:delchomihajlov@yahoo.com

Received 19 February 2004, accepted 4 August 2004

\section{Introduction}

Two field trips conducted by the Centre for Biospeleology of Southeast Europe (Belgrade) and the Natural History Museum of Macedonia (Skopje) over Serbia and the Republic of Macedonia during 2002 and 2003 revealed the presence of three new cave species of the leiodids Petkovskiella Guéorguiev (Petkovskiella henrikenghoffi sp. n.), Babuniella Z. Karaman (Babuniella jovanhadzii sp. n.), and Magdelainella Jeannel (Magdelainella milojebrajkovici sp. n.).

The distribution of the genera Petkovskiella and Babuniella is restricted to the southern part of the Balkan Peninsula (Republic of Macedonia). The genus Petkovskiella comprises a single spe- cies, $P$. stygia (Z. Karaman), while only two species are included in Babuniella: B. ovata Z. Karaman and B. prouzai Udržal \& Moravec (Karaman 1954, Guéorguiev 1976, Udržal \& Moravec 1999).

Six species of Magdelainella Jeannel have been reported until now from south-western areas of the Balkan Peninsula (Pretner 1968, Curčić \& Brajković 2002). All species of the genus are endemic either to a certain mountain range or to a single or several cave systems.

This study comprises descriptions and diagnoses of the new leiodid taxa. The type specimens of the new species are deposited in the collection of the Centre of Biospeleology of Sotheast Europe, Belgrade, Serbia, as well as in the National 
Museum of Natural History, Skopje, Republic of Macedonia.

\section{Systematic part: Leiodidae Fleming}

\subsection{Petkovskiella henrikenghoffi S. B. Ćurčić \& B. P. M. Ćurčić, new species (Figs. 1-2)}

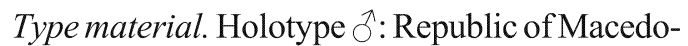
nia, Prilep, Mt. Dautica, 1,300 m a.s.1., v. Zrze, Manastirska Propast Pit, 22.VI.2002, leg. B. M. Mitić; 5 paratype $\delta \hat{o}$ and 12 paratype $\phi$ + , same collecting data as in the holotype; one paratype $P$, Republic of Macedonia, Prilep, Mt. Dautica, 1,300 m a.s.1., v. Zrze, Manastirska Propast Pit, 2.VIII.2001, leg. N. Angelov.

Diagnosis. The species $P$. henrikenghoffi sp. $\mathrm{n}$. is easily distinguished from its only congener, P. stygia (Karaman, 1954) by the different body size, by the shape of antennomere I, by the shape of head, pronotum and elytra, by the form of mesosternal carina, by the different shape of aedeagus, by the shape of paramerae, by the different parameral setation, and by the form of the inner sac (Figs. 1-2).

Description. Middle-sized. Body length 3.67-4.28 mm (average $4.04 \mathrm{~mm}$ ). Body lepto-

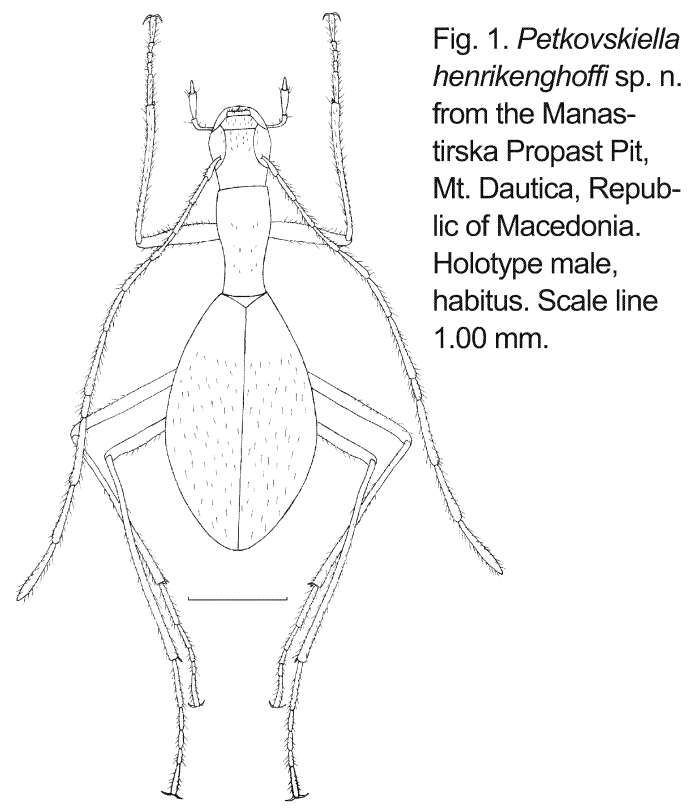

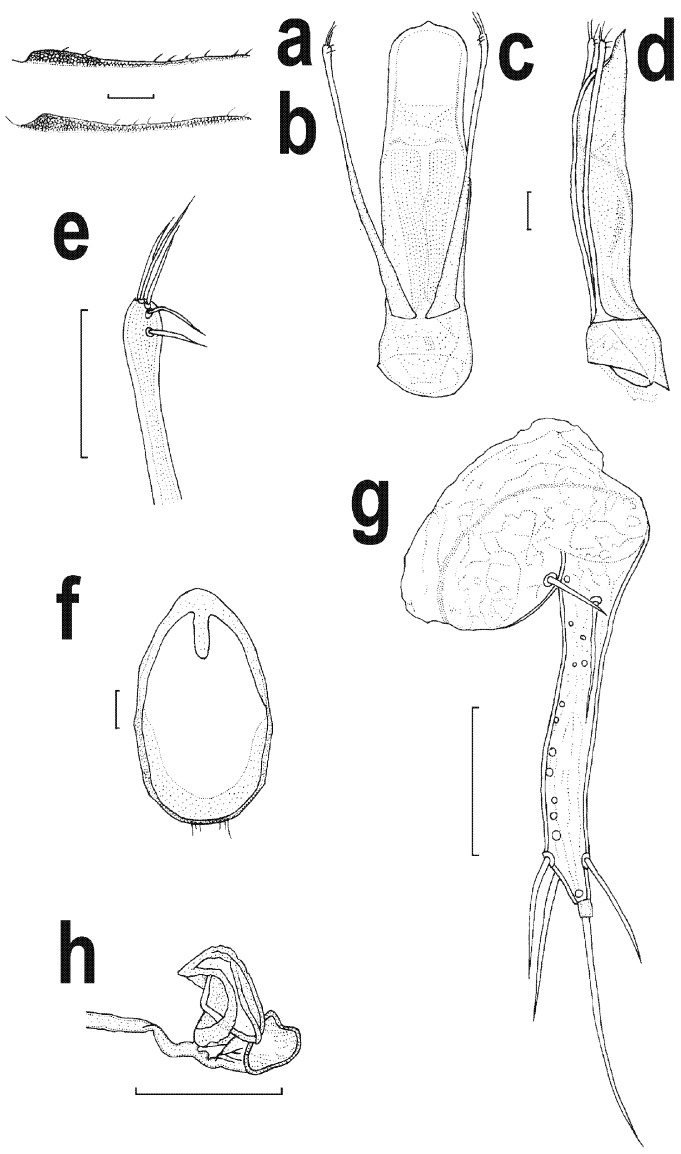

Fig. 2. Petkovskiella henrikenghoffi sp. n. from the Manastirska Propast Pit, Mt. Dautica, Republic of Macedonia (except b). - a. Paratype male, mesosternal carina (lateral view). - b. Petkovskiella stygia (Karaman) from the Damjanica Cave, Mt. Jakupica, Republic of Macedonia; topotype male, mesosternal carina (lateral view). - c. Holotype male, aedeagus with inner sac (dorsal view). - d. Holotype male, aedeagus with inner sac (lateral view). - e. Holotype male, left parameral apex (dorsal view). - f. Holotype male, genital sternite (urite). - g. Paratype female, left stylus (dorsal view). $-h$. Paratype female, spermatheca. Scale bars $0.10 \mathrm{~mm}$.

diroid, elongated (Fig. 1); tegument dark reddish to brownish. Surface of head, elytra, legs, antennae and palpi pubescent; even pronotum with some tiny microsetae.

Head elongated, eyeless, without occipital carina, widest at its anterior part, broader than in $P$. stygia (Fig. 1).

Antennae inserted in the second third of the 
head, filiform, elongated and thin, surpassing the body length.

Pronotum long, elongated (maximum width/ length ratio $0.50-0.53$ ), with a few short discal setae (Fig. 1). Pronotum constricted posteriorly. Anterior pronotal margin straight; pronotal base convex. Pronotum widest immediately after its anterior third (widest after its anterior quarter in $P$. stygia). Disc glabrous, with tiny punctures.

Mesosternal carina low, only barely visible, obtuse-angled (vs. with prominent angle in $P$. stygia), concave medially, with 8 small setae, gradually narrowing distalwards (sharply narrowing distalwards in $P$. stygia) (Fig. $2 \mathrm{a}-\mathrm{b}$ ).

Elytra elongated, ovoid (maximum length/ width ratio $1.49-1.75$ ), narrowing basally, widest below the mid-elytra level (widest at the midelytra level in P. stygia). Elytral disc convex, hairy, with impressed punctures (Fig. 1).

Legs thin and elongated. Femora constricted before their distal ends. Metafemora narrowing basally (Fig. 1).

Aedeagus moderately long, wide, narrowing (lateral view; Fig. 2d) and pointed apically (dorsal view; Fig. 2c). Aedeagus slightly narrowing distally, somewhat broader and longer than in $P$. stygia (Fig. 2d), its top being thinner than in $P$. stygia (Fig. 2c). Paramerae elongated, slightly shorter than aedeagus (Fig. 2c), each carrying 5 setae. Parameral apex narrow (Fig. 2e). Saccus internus with 2 longitudinal strips and some inconspicuous sclerifications in front of these strips (Fig. 2c).

Male gonosternite IX (urite) subovate, setose, with an internal process (Fig. 2f).

Female styli as in Fig. 2g. Gonostyli elongated, pointed, narrowed, and curved distally. Each stylus with a single apical and two inner setae (one exterior and one proximal seta; Fig. $2 \mathrm{~g}$ ). Spermatheca small, asymmetrical, divided in two funnel-like parts (Fig. 2h). Spermatheca inconspicuously sclerified.

Bionomy and distribution. This new species inhabits the walls at the end of the pit $(-15 \mathrm{~m}) . P$. henrikenghoffi $\mathrm{sp}$. $\mathrm{n}$. is specialized for filtrating organic matter from the water found on pit walls. It is known only from the Manastirska Propast Pit on Mt. Dautica, Republic of Macedonia, and represents an endemic and relict form ( $\sim$ "living fossil") of the Tertiary origin (Fig. 3).

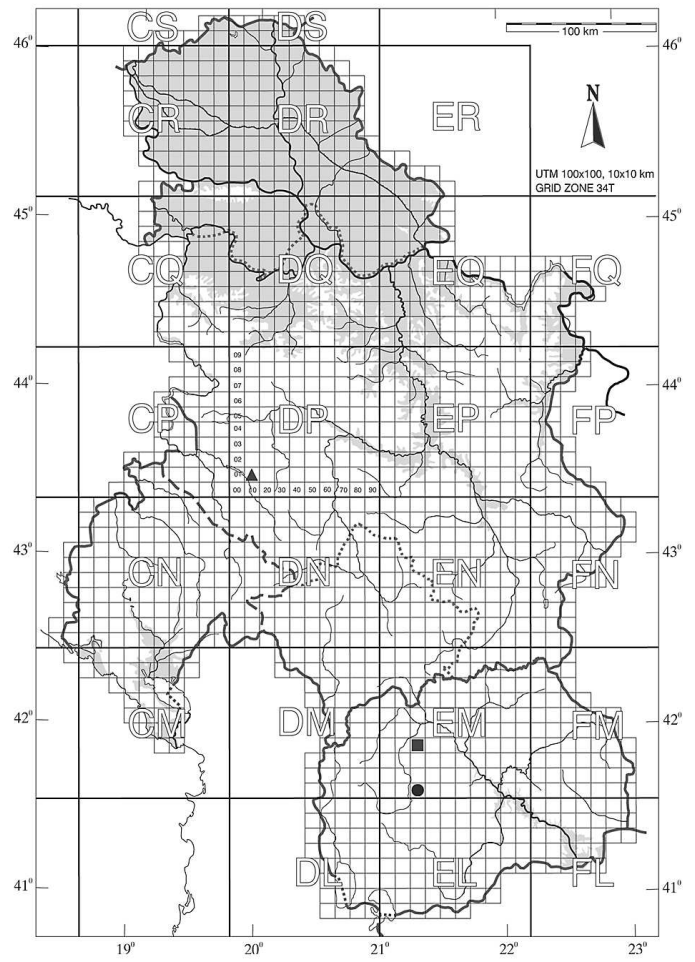

Fig. 3. Distribution of the new leiodid species from Serbia and Republic of Macedonia. Solid circle = Petkovskiella henrikenghoffi sp. n.; solid square = Babuniella jovanhadzii sp. n.; solid triangle = Magdelainella milojebrajkovici sp. n. Scale in km.

Etymology. After the name of a noted Danish evolutionist and zoologist, Prof. Dr. Henrik Enghoff(Copenhagen).

\subsection{Babuniella Z. Karaman, new status}

Synonymy: Hussonella (Babuniella) Jeannel, Acta Mus. Mac. Sci. Nat., 1954, 2: 65-91.

Type species: Babuniella ovata Z. Karaman, 1954.

Other species: Babuniella prouzai Udržal \& Moravec, 1999 and Babuniella jovanhadzii sp. n.

Diagnosis. The genera Babuniella $\mathrm{n}$. stat. and Hussonella Jeannel differ in the: body length (3.00-3.50 $\mathrm{mm}$ vs. $2.80-3.20 \mathrm{~mm}$ ), body form (more vs. less elongated), form of antennomere VIII (longer than wide vs. as long as wide), form of mesosternal carina (with anterior tooth vs. without anterior tooth), position of pygidium (covered by elytral apex vs. protruding beneath 
elytra), form of elytra (elongated vs. ovoid), form of median lobe of aedeagus (elongated, laterally impressed and constricted in its apical third vs. less elongate, laterally regularly curved, and not constricted in its apical third), form of inner sac of aedeagus, length of parameres (longer than median lobe vs. as long as median lobe), form of parameres (apically thin, protruding exteriorly and not pointed distally vs. apically thickened, not protruding exteriorly and pointed distally), form (straight vs. curved) and position of parameral setae (one lateral subapical interior seta, one dorsal subapical seta and another subapical dorsal seta vs. one lateral apical exterior seta, one subapical ventral seta and another subapical ventral seta), and setal distance (II-III longer than III vs. I-II longer than II-III) (Jeannel 1934) (Figs. 4-5).

At present the genus Babuniella comprises three species from the Republic of Macedonia: B. ovata, B. prouzai, and B. jovanhadzii sp. n. One of these is endogean (B. prouzai; Mt. Jakupica) and the remaining two are troglobitic ( $B$. ovata from the Damjanica Cave, v. Nežilovo, Mt. Jakupica; and B. jovanhadzii sp. n. from the Špela Bozguni Cave, v. Patiška Reka, Mt. Karadžica) (Karaman 1954, Udržal \& Moravec 1999).

Distribution. The genus Babuniella is presently known from some caves and endogean localities on Mts. Jakupica and Karadžica in the northern and central parts of the Republic of Macedonia.

Etymology. After Mt. Babuna, its terra typica.

Remarks. We suggest that Babuniella belongs to a separate phyletic lineage that originated during or even before the Paleogene. Its endemic differentiation was facilitated by the great Alpine Orogeny, suitable paleoclimatic events, as well as by the subsequent evolution of the underground karstic relief. It is evident that Babuniella represents an endemic and relict form both to the Republic of Macedonia and to the Balkan Peninsula.

\subsection{Babuniella jovanhadzii S. B. Ćurčić \& B. Mihajlova, new species (Figs. 4-5)}

Type material. Holotype $\lesssim$ (Fig. 4): Republic of Macedonia, Skopje, Mt. Karadžica, 1,300 m a.s.1., v. Patiška Reka, Špela Bozguni Cave,

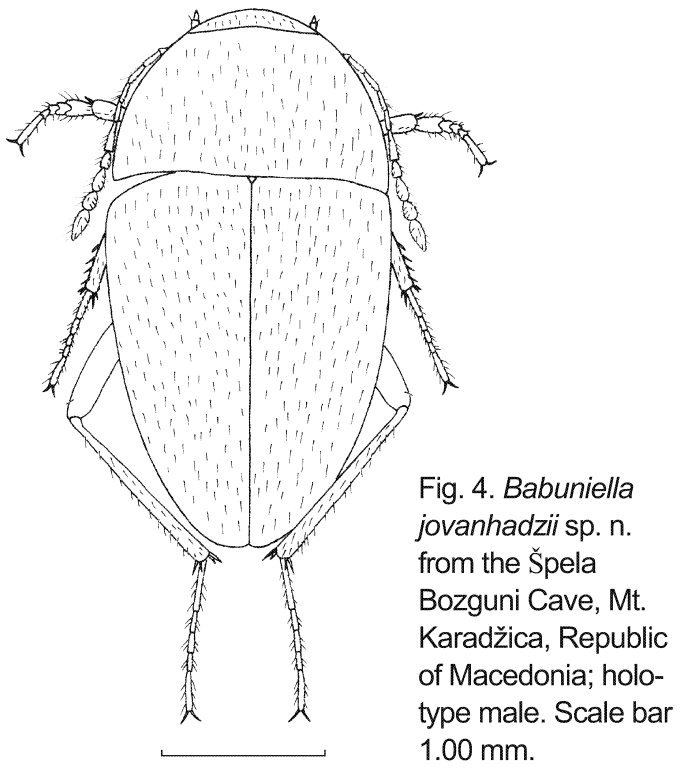

20.VI.2002, leg. S. B. Ćurčić; one paratype $\widehat{\jmath}$ and 5 paratype $q+$, same data as for the holotype, collected by S. B. Ćurčić, B. M. Mitić, S. E. Makarov \& N. Angelov; one paratype 9 , Republic of Macedonia, Skopje, Mt. Karadžica, 1,300 m a.s.l., v. Patiška Reka, Špela Bozguni Cave, 14.VII.2000, collected by E. Stojkoska.

Diagnosis. The new species $B$. jovanhadzii $\mathrm{sp}$. $\mathrm{n}$. is clearly distinct from the two other congeners by the body size and form of head, pronotum and elytra, shape of antennomeres, form of mesosternal carina, shape of aedeagus, shape of paramerae, different position of parameral setae, form of the male genital segment, and by the form of the armature of the inner sac (Figs. 4-5).

Description. Middle-sized. Body length 2.93-3.30 mm (average $3.16 \mathrm{~mm}$ ). Body bathyscioid, ovoid, convex (Fig. 4); tegument chestnut-brown, lustrous, with some tiny yellowish hairs and microsculptures.

Head subquadrate, with sculptures, inconspicuously punctate, slightly narrower than in B. prouzai. Eyes absent. Occipital carina present.

Antennae moderately long and slender, reaching the level of the anterior fourth of elytral length. Antennomeres I and II long and thickened; III and IV short and narrow, but antennomere III somewhat longer than IV; antennomeres $\mathrm{V}$ and VI short, V slightly longer than VI; antennomere VII long, thickening distally; an- 
tennomere VIII is shortest, subellyptic, longer than wider; IX and X moderately long and thick, IX somewhat longer than X; antennomere XI is longest and thick, narrowing distally. There are clear differences between $B$. jovanhadzii sp. n., $B$. ovata and $B$. prouzai in the length ratios of antennomeres III-VII and XI, as well as in the form of antennomeres VIII, IX and XI (Fig. 4).

Pronotum transverse, convex, maximal width/length ratio: 1.69-1.79 (pronotum 1.70 times as wide as long in B. prouzai, and twice as wide as long in B. ovata) (Karaman 1954, Udržal \& Moravec 1999). Anterior pronotal angles obtuse and prominent. Anterior pronotal margin slightly protruding forwards. Lateral margins abruptly arcuate posteriorly. Pronotum widest basally. Posterior pronotal angles rounded and obtuse. Pronotal base somewhat convex in its middle part and curved posteriorly (in B. prouzai, pronotal base is straight in its middle part); pronotal disc microreticulate and scarcely punctate.

In B. jovanhadzii sp. n., mesosternal carina high, obtuse, with a small tooth anteriorly (in another two species of the genus, shape of mesosternal carina is different and its tooth is sharp and prominent; Fig. 5a). Its posterior margin with a dozen of short setae (which lack in other Babuniella species). Posterior apophysis not exceeding the level of metasternum.

Elytra elongated, ovoid, widest at the level of their anterior quarter, rounded apically (widest basally, with a rounded apex in B. ovata vs. widest anterior to their mid-level, with oblique apex in $B$. prouzai), elytral width/length ratio: 0.80 0.87 (0.88 in B. prouzai; Udržal \& Moravec 1999) (Fig. 4). Lateral margins arcuated, narrowing apically, elytra covering the pygidium. Sutural striae absent. Elytral disc convex, with sparse punctures, otherwise arranged in regular transverse series.

Male genital segment (Fig. 5e) bottle-shaped, with two elongated terminal and internal processes.

Protibia slender, somewhat thickened distally. Male protarsi pentamerous, their articles dilated (Fig. 4). Mesotibiae arcuate, covered with bristles on their exterior margins. Metatibiae slender and straight. Tarsal claws simple.

Aedeagus (Fig. 5b-c) large, elongated, 1.45

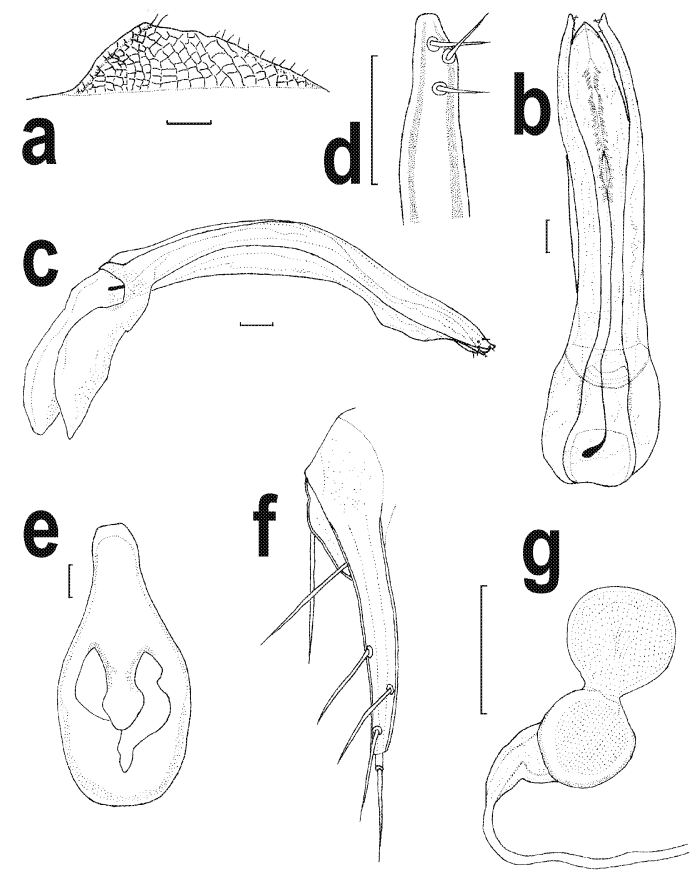

Fig. 5. Babuniella jovanhadzii sp. $n$. from the Špela Bozguni Cave, Mt. Karadžica, Republic of Macedonia. - a. Holotype male, mesosternal carina (lateral view). - b. Holotype male, aedeagus with inner sac (dorsal view). - c. Holotype male, aedeagus (lateral view). d. Holotype male, left parameral apex (dorsal view). e. Holotype male, genital sternite (urite). - f. Paratype female, left stylus (dorsal view). - g. Paratype female, spermatheca. Scale bars $0.10 \mathrm{~mm}$.

mm long [1.34 mm in B. prouzai; Udržal \& Moravec (1999)]. Tegmen broad. Edges of median lobe subparallel dorsally and curved laterally. Median lobe constricted in its anterior part, apex with a tiny terminal protuberance. Paramerae long, slender, exceeding the length of apex of aedeagus. Apex of each paramere oblique, flattened (sharp in B. prouzai), with 3 setae on its inner margin (Fig. 5d). Lateral subapical inner seta is close to dorsal subapical seta (these setae are more distant in B. ovata). Armature of inner sac (Fig. 5b) includes a long apical sclerification and a long fibre ending as a sphaerical ampulla.

Female styli as in Fig. 5f. Gonostyli elongated, thorn-like, narrowing distally, slightly curved. Each stylus with a single apical seta, three inner and one outer seta (Fig. 5f). Spermatheca small, of two fused sphaerical parts, constricted laterally (Fig. 5g). Spermatheca well-sclerified. 
Bionomy and distribution. Individuals of the new species were collected under stones and from the humus and soil, near the entrance of the cave. These cave beetles are detritophagous and their diet is restricted to organic matter from the cave walls and ground. B. jovanhadzii sp. n. is known only from Špela Bozguni Cave on Mt. Karadžica, Republic of Macedonia, and represents an endemic and relict form, probably of the early Tertiary origin (Fig. 3).

Etymology. After a noted Serbian evolutionist, the late academician Jovan Hadži (Ljubljana).

\subsection{Magdelainella milojebrajkovici} S. B. Ćurčić \& B. P. M. Ćurčić, new species (Figs. 6-7)

Type material. Holotype $\widehat{\jmath}$ (Fig. 6): Serbia, Nova Varoš, Mt. Javor, 1,350 m a.s.l., v. Trudovo, Žuta Pećina Cave, 23.VIII.2003, coll. S. B. Curčić.

Diagnosis. From its phenetically close subgener, Magdelainella bozidarcurcici Ćurčić $\&$ Brajković (from Serbia), the new species is clearly distinct by the body size, shape of pronotum and elytra, length of antennae and shape of some antennomeres, form of mesosternal carina, shape of aedeagus, shape of paramerae, position of their setae, and by the form of the armature of inner sac (Figs. 6-7).

Description. Small-sized. Body length with straightened head: $2.46 \mathrm{~mm}$. Body bathyscioid, ovoid, convex (Fig. 6); tegument brownish, shiny, with short yellowish hairs, and with some microsculptures.

Head subquadrate (Fig. 6), with tiny sculptures and small punctures. Eyes absent. Occipital carina present.

Antennae short, not reaching the level of the pronotum base (vs. reaching the pronotal base in M. bozidarcurcici Ćurčić \& Brajković; Ćurčić \& Brajković 2002). Antennomeres I and II long; antennomere III small, almost twice as long as wide, slightly shorter than demi-antennomere II; IV-VI similar to III, gradually thickening from IV to VI; antennomere VII thickened, length/ width ratio 1.20 [1.33 in M. bozidarcurcici; Ćurčić \& Brajković (2002)]; antennomere VIII small, twice as short as the preceding article; IX and X larger than VIII; antennomere XI some-

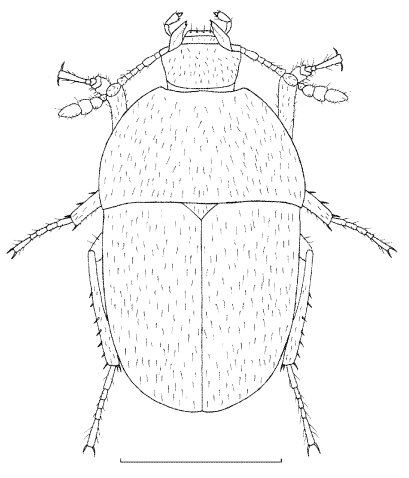

Fig. 6. Magdelainella milojebrajkovicisp. n. from the Žuta Pećina Cave, Mt. Javor, Southwestern Serbia; holotype male, habitus. Scale bar $1.00 \mathrm{~mm}$.

what longer than wide [twice as long as wide in M. bozidarcurcici; Ćurčić \& Brajković (2002)], and as long as antennomerae IX $+\mathrm{X}$ together (Fig. 6). Maxillary palps each with a small conical distalmost article.

Pronotum convex, maximum width/length ratio 1.76 [1.69-2.00 in M. bozidarcurcici; Ćurčić \& Brajković (2002)], with some short laid discal pubescence (Fig. 6). Anterior pronotal angles obtuse (prominent in M. bozidarcurcici). Anterior pronotal margin protruding forwards. Lateral pronotal margins regularly arcuated; pronotal base length greater than maximum elytral width. Pronotum widest at the level of its third fourth. Pronotal base somewhat convex in its median part (vs. pronotal base straight in its median part in M. bozidarcurcici; Ćurčić \& Brajković 2002). Pronotal disc with microsculpture and some tiny punctures.

Mesosternal carina high (Fig. 7a), obtuse, with a large obtuse tooth (vs. less prominent tooth in M. bozidarcurcici; Fig. 7b). Margins of mesosternal carina slightly convex (vs. almost straight in M. bozidarcurcici; Fig. 7b). The tooth of mesosternal carina with 4 setae ( 8 setae are carried both on the tooth as well as on the posterior margin of mesosternal carina in $M$. bozidarcurcici; Fig. 7b). Intercoxal apophysis narrow.

Elytra short, ovoid (Fig. 6), widest at the level of their anterior quarter (widest just below the elytral base in $M$. bozidarcurcici), rounded apically, width/length ratio 0.87 [0.89-0.97 in $M$. bozidarcurcici; Ćurčić \& Brajković (2002)]. Elytra inconspicuously impressed in their anterior and lateral parts (this character is not seen in M. bozidarcurcici). Lateral margins arcuate, narrowing apically. Elytral disc convex, covered 


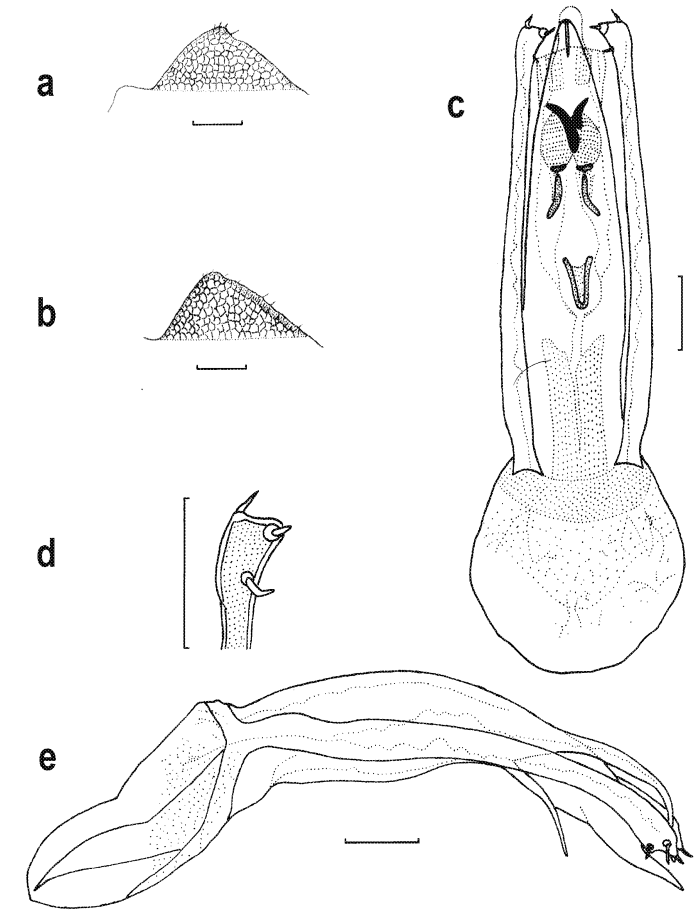

Fig. 7. Magdelainella milojebrajkovici sp. $\mathrm{n}$. from the Žuta Pećina Cave, Mt. Javor, Southwestern Serbia (except b). - a. Holotype male, mesosternal carina (lateral view). - b. Magdelainella bozidarcurcici Ćurčić \& Brajković from the Pećina pod Kapilijama Cave, Mt. Javor, Southwestern Serbia; holotype male, mesosternal carina (lateral view). - c. Holotype male, aedeagus with inner sac (dorsal view). - d. Holotype male, aedeagus (lateral view). - e. Holotype male, left parameral apex (dorsal view). Scale bars $0.10 \mathrm{~mm}$.

with short and laid setae, and with some impressed punctures. Sutural striae present. Scutellum triangular, moderately large (Fig. 6).

Legs attenuated (Fig. 6). Protarsi pentamerous and dilated in males. Protibiae dilated distally. Mesotibiae moderately arcuated, each with 4 bristles on their exterior margin. Metatibiae somewhat arcuated (almost straight).

Aedeagus (Fig. 6c-d) moderately long, slightly arcuated, narrowing (lateral view; Fig. 6d) and pointing apically (dorsal view; Fig. 6c). Tegmen rounded, more elongate than in $M$. bozidarcurcici. Median lobe constricted in its posterior part. Apex rounded (vs. sharp in $M$. bozidarcurcici). Paramerae long, slender, not reaching the level of the median lobe apex (vs. paramerae reaching the level of the median lobe apex in M. bozidarcurcici) (Fig. 6c). Parameral apex broad, convex exteriorly (Fig. 6e) (vs. flattened exteriorly in $M$. bozidarcurcici), with 3 curved setae: one lateral exterior seta, one laterodorsal internal seta, and one subapical dorsal seta (Fig. 6e). Dorsal subapical seta is more distant from laterodorsal internal seta than in $M$. bozidarcurcici.

Saccus internus with a sclerified complex armature (Fig. 6c). Two simple teeth [two bifid teeth in M. bozidarcurcici; Ćurčić \& Brajković (2002)], situated distally in the inner sac. Two lamellar parts exist just below the teeth. Chitinized median subtriangular gutter-formed structure is situated in the inner sac. Two weakly chitinized bands occur basally in the inner sac (vs. absent in $M$. bozidarcurcici).

Female unknown.

Bionomy and distribution. The type specimen of the new species was found on a cave wall, in total darkness ( $20 \mathrm{~m}$ from the cave entrance). Magdelainella milojebrajkovici $\mathrm{sp}$. $\mathrm{n}$. is known only from Žuta Pećina Cave on Mt. Javor, Serbia, and represents an endemic and relict form of the Tertiary origin and age (Fig. 3).

Etymology. After the name of Prof. Dr. Miloje Brajković, a noted Serbian zoologist and the former president of the Serbian Entomological Society.

\section{Discussion and conclusions}

Holdhaus (1932) adopted the botanist term "massifs de refuge" in explaining the distribution of the boreo-alpine insects, particularly Coleoptera. He has assumed that the southern area of the Alps (and the low-altitude regions of the Balkan Peninsula) has remained ice-free during the whole of Pleistocene and has served as the survival refugium for the autochthonous species. A number of species, including the leiodids considered in this paper, appear to be exclusively confined to the massifs de refuge. Some of these taxa (belonging to the genera Petkovskiella, Babuniella, and Magdelainella) occur on isolated single summits in the western and southern areas of the Balkan Peninsula [Serbia, Republic of Macedonia; Ćurčić (1988)].

In contrast to the intensely glaciated central 
and northern Alps, the area of the massifs de refuge (i.e. the most of the Balkan Peninsula, including the Dinarids, Carpathians, and Mt. Balkan) contained, during the Pleistocene, numerous unglaciated areas and the altitude of the snowline during the glacial times permitted the occurrence of both forests and karstification at much lower elevations in the region of the marginal mountains (Schweiger 1950).

As at the present times, even during the Pleistocene the southern margin of different mountains and cave habitats had protected suitable conditions, thus enabling a great number of leiodid taxa to survive. It is because of this that the refuges (including habitats underground) have at present a rich petrophile (including cave- and soil-dwelling) fauna of leiodid coleopterans, while the other localities are poor in them (Birstein 1947, Birstein \& Ljovuschkin 1967).

In conclusion, both the Dinaric Karst sensu stricto and the Hellenids (the Dinarids of Albania, Republic of Macedonia and Greece) are inhabited by a great number of endemic and relict cave leiodids pertaining to the Laurasian, Paleo-Mediterranean, Paleo-Aegean, and South- or NorthAegean phyletic series. Among the major causes which explain the extraordinary variety of the troglobitic leiodid coleopteran fauna of the area studied one should mention: (i) a varied epigean leiodid fauna populating the Proto-Balkans in the remote past; (ii) the continuity of the continental phase in different areas of the Balkans (and the Dinaro-Hellenid Region in particular); (iii) the presence of limestone beds and the subsequent evolution of the pre-glacial karst relief; (iv) the succession of the climatic conditions which favoured the colonization of the subterranean milieux; and (v) the divergent differentiation of the leiodid taxa in numerous hypogean and other underground habitats.

This study of some cave representatives of the endemic and relict genera Petkovskiella, Babuniella and Magdelainella from the Republic of Macedonia and Serbia, respectively, has offered further proof of their great age and different origin. These species and genera represent the last vestiges of an old fauna, which found their shelter in the underground domain of the western and southern parts of the Balkan Peninsula and, probably, of some adjoining regions.
Acknowledgements. We are deeply grateful to Dr. Heinrich Schönmann (Vienna) who loaned us the specimens of Petkovskiella stygia (Z. Karaman) from the Natural History Museum in Vienna. We also appreciate the help of Nikola Angelov (Skopje) from the Speleological Society "Peoni" who collected some specimens of Petkovskiella treated herein. Dr. Darko Stamenov (Vienna) provided necessary literature for this study. Our gratitude is due also to Vladimir Tomić, M. Sc. (Belgrade), for his excellent technical assistance. This study is supported by the Serbian Ministry for Science, Technologies and Development Grant 1547 and by a grant from the National Museum of Natural History in Skopje.

\section{References}

Birstein, Ya. A. 1947: Poniatie "relikt" v biologii (The conception of "relict" in biology). — Zoologicheski Zhurnal 26: 313-330.

Birstein, Ya. A. \& Ljovuschkin, S. I. 1967: Some results and problems in studying of the subterranean fauna of the USSR. - Zoologicheski Zhurnal 46: 1509-1535.

Ćurčić, B. P. M. 1988: Cave-dwelling Pseudoscorpions of the Dinaric Karst. - Academia Scientiarum et Artium Slovenica, Classis IV: Historia Naturalis, Opera 26, Institutum Biologicum Ioannis Hadži, 8, Ljubljana. $192 \mathrm{pp}$.

Ćurčić, S. B. \& Brajković, M. M. 2002: Magdelainella bozidarcurcici sp. n. (Coleoptera, Cholevidae), a new endemic beetle from southwest Serbia. - Archives of Biological Sciences (Belgrade) 53 (3-4): 97-100.

Guéorguiev, V. B. 1976: Recherches sur la taxonomie, la classification et la phylogénie des Bathysciinae (Coleoptera: Catopidae). - Razprave IV razreda SAZU 19 (4): 91-147.

Holdhaus, K. 1932: Die europäische Höhlenfauna in ihren Beziehungen zur Eiszeit. - Zoogeographica 1: 1-53.

Jeannel, R. 1934: Bathysciinae recueillis par MM. Rémy et R. Husson dans le Sandjak de Novi-Pazar et la Macédoine grecque. - Revue Française d'Entomologie 1: 89-103.

Karaman, Z. 1954: Weitere Beiträge zur Kenntnis der mazedonischen Coleopteren-Fauna. - Acta Musei Macedonici Scientiarum Naturalium (Skopje) 2: 6591.

Pretner, E. 1968: Catalogus Faunae Jugoslaviae. III/6. Coleoptera, Fam. Catopidae, Subfam. Bathysciinae. Academia Scientiarum et Artium Slovenica, 3 (4), Ljubljana. 59 pp.

Schweiger, H. 1950: Der Einfluss der Einzeit auf die Verbreitung der Ostalpinen Trechusarten. - In: Elfström, A. R. (ed.), Proceedings of the Eighth International Congress of Entomology, Stockholm (1948): 489 496. Stockholm. 1030 pp.

Udržal, R. \& Moravec, J. 1999: New species of the genera Albaniola and Hussonella (Coleoptera: Leiodidae: Leptodirini) from Macedonia. - Folia Heyrovskyana 7 (1): $33-44$. 